\title{
Gas exchanges and water-use efficiency of Nopalea cochenillifera intercropped under edaphic practices
}

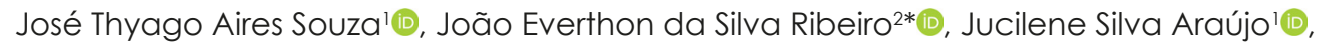 \\ João Paulo de Farias Ramos² ${ }^{2}$, José Pereira do Nascimento ${ }^{3}\left[\right.$, Leonardo Torreão Villarim de Medeiros ${ }^{4}[0$ \\ 'National Semiarid Institute, Campina Grande, Brazil \\ ${ }^{2}$ Federal University of Paraíba, Areia, Brazil \\ ${ }^{3}$ Secretariat of Education, Science and Technology of Paraiba, João Pessoa, Brazil \\ ${ }^{4}$ Paraíba Research Company, Rural Extension and Land Regularization, Soledade, Brazil \\ *Corresponding author, e-mail: j.everthon@hotmail.com
}

\begin{abstract}
The Nopalea forage cactus (Nopalea cochenillifera) is the main xerophilic species cultivated in Brazil, highlighted as a compatible biological element with the semiarid environment. However, studies on its physiological aspects are still scarce. In this context, an experiment was performed in the Pendência Experimental Station, belonging to the State Company of Agricultural Research of Paraíba (EMEPA-PB), municipality of Soledade, state of Paraíba, Brazil, aiming to evaluate the gas exchanges and the water-use efficiency of intercropped Nopalea Cochenillifera plants in the soil under different edaphic managements. The treatments were distributed in randomized blocks, with three replications in a $2 \times 5$ factorial scheme, corresponding to the soil without and with mulch and five types of cultivation of Nopalea forage cactus, in monoculture and intercropped with forage watermelon, millet, sorghum, and buffelgrass. The analyzed variables were: stomatal conductance, transpiration rate, net photosynthesis rate, and internal $\mathrm{CO}_{2}$ concentration, besides the instantaneous wateruse efficiency, intrinsic water-use efficiency, and instantaneous carboxylation efficiency. The use of soil mulch satisfactorily increased the photosynthetic rate of the forage cactus; this type of practice can aid in the productive development of the crop in semiarid zones, whereas the intercropping with buffelgrass and forage watermelon stimulated photosynthesis and the water-use efficiency.
\end{abstract}

Keywords: Cactaceae, intercropping, mulch, photosynthesis

\section{Introduction}

The Nopalea forage cactus (Nopalea cochenillifera Salm-Dyck) is the main xerophilic species cultivated in Brazil, being an essential food source for cattle, sheep, and goat herds in the semiarid region, especially in the dry season (Lima et al., 2018). Ramos et al. (2017) highlight that this crop is highly incorporated into the productive process of the region, being essential for the maintenance of yield and animal support capacity, especially in small rural properties, which constitute the majority of properties in the semiarid region.

This cactus species is governed by the crassulacean acid metabolism, with the characteristic of fixing $\mathrm{CO}_{2}$ to phosphoenolpyruvic acid by the action of the PEP-case enzyme, during the night. Thus, carbon is assimilated in the form of organic acids, aspartic acid, and malic acid, which are accumulated in the vacuoles. During the day, these plants save water with their closed stomata since they have already assimilated $\mathrm{CO}_{2}$, and then decarboxylate these organic acids by the same $\mathrm{C}_{4}$ decarboxylation pathways, providing the $\mathrm{CO}_{2}$ for the Calvin-Benson cycle, which depends on luminous energy (Nobel, 2009).

In these conditions, the intercropped cultivation of the forage cactus with other plant species can positively influence the efficient use of land and water, besides the environment-plague interactions, the occurrence of spontaneous plants, and the mutual physiological cooperation of the Nopalea forage cactus and its intercropped species, reflecting in productive gains per unit of area, which, in most cases, are greater than in single farming systems (Sampaio, 2005; Silva et al., 2013; Jardim et al., 2018).

This system has been adopted by producers with the purpose of making the agricultural practices economically viable and, therefore, obtaining an extra 
income with the higher land yield (Andrade et al., 2015). In the specific case of the Nopalea forage cactus, which is constituted by $90 \%$ of water, this production model also presents another particularity, which is the compensation in the dry matter yield by other crops, especially tropical grasses for the elaboration of more balanced diets to animals (Silva et al., 2011; Diniz et al., 2017).

Both in intercropped and in monoculture systems, the use of conservationist techniques, such as mulch, besides minimizing the wearing effect by the direct impact of raindrops on the soil and reducing the temperature of the root environment, can also aid in the decomposition of residues, increasing the content of organic matter, the cycling capacity, and, consequently, the availability of nutrients to the crops.

Tomas et al. (2014) and Sun et al. (2018) highlight that, in semiarid zones, the use of the edaphic cover with vegetal remains can propitiate a better physiological activity and water-use efficiency by plants. Although this technique has been used for a long time in the semiarid, such as the intercropping of the Nopalea forage cactus, physiological studies on the interaction of intercropped crops are still scarce and need to be quantified. In this perspective, this work aimed to evaluate the gas exchanges and the water-use efficiency of Nopalea cochenillifera cultivated in intercropping in soil under different edaphic managements.

\section{Material and Methods}

The experiment was performed in the Pendência Experimental Station (EEPEN), belonging to the State Company of Agricultural Research of Paraíba (EMEPA-PB), municipality of Soledade-PB (7० 8' 18" S and 36 27' 2" W). Based on the classification by Köppen, the municipality presents a BSh climatic type, hot semiarid, with rainfall from March to June, mean annual temperatures around $30^{\circ} \mathrm{C}$, air relative humidity around $68 \%$, and mean annual rainfall of 388.2, presenting water deficit during most of the year (Alvares et al., 2013).

According to the criteria of the Brazilian System of Soil Classification - SiBCS (EMBRAPA, 2013), the soil of the experimental area was classified as a Eutrophic FLUVIC NEOSOL. Before planting the annual crops, 15 single soil samples were collected in the experimental area at a 0-20 cm depth, later turned into a compound sample. Afterward, the sample was sent for physical and chemical characterization at the Laboratory of Soils, belonging to the Department of Soils and Rural Engineering of the Center of Agricultural Sciences, Federal University of Paraíba (CCA/UFPB), in the municipality of Areia-PB, (Table 1). The soil samples were collected at a $0-20 \mathrm{~cm}$ depth since the
Nopalea forage cactus presents a superficial root system, with approximately $75 \%$ distributed at this depth (Santos et al., 2017).

Table 1. Chemical characterization of fertility and physics of the soil in the $0-20 \mathrm{~cm}$ layer.

\begin{tabular}{|c|c|c|c|}
\hline \multicolumn{4}{|c|}{ Soil characterization } \\
\hline Chemical attributes & Value & Physics attributes & Value \\
\hline $\mathrm{pH}\left(\mathrm{H}_{2} \mathrm{O}\right)$ & 6.20 & $\mathrm{SD}\left(\mathrm{kg} \mathrm{dm^{-3 } )}\right.$ & 1.31 \\
\hline$P\left(\mathrm{mg} \mathrm{dm}^{-3}\right)$ & 70.30 & $\mathrm{PD}\left(\mathrm{kg} \mathrm{dm^{-3 } )}\right.$ & 2.68 \\
\hline $\mathrm{K}\left(\mathrm{cmol}_{\mathrm{c}} \mathrm{dm}^{-3}\right)$ & 0.21 & Sand $\left(\mathrm{g} \mathrm{kg}^{-1}\right)$ & 629.00 \\
\hline $\mathrm{Na}^{+}\left(\mathrm{cmol}_{\mathrm{c}} \mathrm{dm}^{-3}\right)$ & 0.16 & Silt $(g$ kg-1) & 180.00 \\
\hline $\mathrm{H}^{+}+\mathrm{Al}^{3+}\left(\mathrm{cmol}_{\mathrm{C}} \mathrm{dm}^{-3}\right)$ & 2.51 & Clay $\left(g_{k g}{ }^{-1}\right)$ & 128.00 \\
\hline $\mathrm{Al}^{3+}\left(\mathrm{cmol}_{\mathrm{c}} \mathrm{dm}^{-3}\right)$ & 0.00 & $\operatorname{Mfc}\left(\mathrm{g} \mathrm{kg}^{-1}\right)$ & 129.00 \\
\hline $\mathrm{Ca}^{2+}\left(\mathrm{cmol}_{\mathrm{c}} \mathrm{dm}^{-3}\right)$ & 3.17 & Mpwp $\left(g^{k g}{ }^{-1}\right)$ & 71.00 \\
\hline $\mathrm{Mg}^{2+}\left(\mathrm{cmol}_{\mathrm{c}} \mathrm{dm}^{-3}\right)$ & 1.95 & Texture & Sandyloam \\
\hline $\mathrm{SB}\left(\mathrm{cmol}_{\mathrm{c}} \mathrm{dm}^{-3}\right)$ & 5.49 & - & - \\
\hline CEC $\left(\mathrm{cmol}_{\mathrm{c}} \mathrm{dm}^{-3}\right)$ & 8.00 & - & - \\
\hline$\vee(\%)$ & 68.60 & - & - \\
\hline $\operatorname{SOM}\left(\mathrm{g} \mathrm{kg}^{-1}\right)$ & 12.40 & - & - \\
\hline
\end{tabular}

The treatments were distributed in randomized blocks, with three replications and fifteen plants per plot, in a $2 \times 5$ factorial scheme corresponding to the soil without and with mulch, and five forms of cultivation of Nopalea forage cactus in dryland farming (monoculture and intercropping with forage watermelon (Citrulus lanatus cv. citroides), forage millet (Pennisetum glaucum), forage sorghum (Sorghum bicolor), and buffelgrass (Cenchrus ciliaris), with all intercropped plants obtained via seeds. The mulch was composed of spontaneous weeds removed from the experimental area and adjacencies after manual hoeing, with a $5 \mathrm{~cm}$ thickness, distributed throughout the experimental plot. For the beginning of the research, an area cultivated with Nopalea cochenillifera plants with two years of age was chosen, with a planting density of 20.000 plants ha-1 ( $1 \times 0.5 \mathrm{~m}$, between rows and plants, respectively). The plants were cut before the installation of the experiment, preserving the primary cladodes in order to maintain the stand, followed by organic fertilization by adding 12.5 t of bovine manure ha-1 (Santos et al., 2008a). The densities of the intercropped crops varied from 10.000 plants ha $^{-1}$ for the forage watermelon $\left(1 \times 1 \mathrm{~m}^{-1}\right.$ between rows and plants, respectively) to 100.000 plants for both grasses ( $1 \times$ $0.1 \mathrm{~m}^{-1}$ between rows and plants, respectively).

After the beginning of the experiment, fertilization was performed based on the results of the soil analysis (Table 1) and the respective recommendation suggested by Santos et al. (2008a) for the forage cactus crop. The remaining crops received fertilization 30 days after germination, also as a function of the soil analysis results 
and the suggestions by Costa et al. (2008) adapted for forage watermelon, Tabosa et al. (2008a) for millet, Tabosa et al. (2008b) for forage sorghum, and Santos et al. (2008b) for buffelgrass. At the beginning of April 2018, the sowing of both crops was performed at $20 \mathrm{~cm}$ from the forage cactus rows, allied to periodic agricultural practices through manual hoeing in the totality of the cultivated area.

The gas exchange variables for the forage cactus were determined at 70 days after the germination of the intercrops by measuring the stomatal conductance $\left(g_{s}\right)\left(\mathrm{mol} \mathrm{m}^{-2} \mathrm{~s}^{-1}\right)$, transpiration rate $(E)$

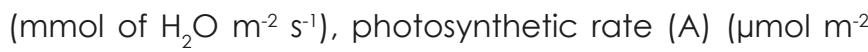
$\mathrm{s}^{-1}$ ), and internal $\mathrm{CO}_{2}$ concentration (Ci) ( $\mu \mathrm{mol}$ of $\mathrm{CO}_{2}$ $\left.\mathrm{mol}^{-1}\right)$. Based on the data, the instantaneous wateruse efficiency (WUE) was calculated by relating the photosynthetic rate with transpiration (A/E), as well as the intrinsic water-use efficiency (iWUE) by relating the photosynthetic rate with stomatal conductance $\left(\mathrm{A} / \mathrm{g}_{s}\right)$, and the instantaneous carboxylation efficiency (iCE) by relating the photosynthetic rate with the internal carbon concentration (A/Ci).

Since the forage cactus is governed by the crassulacean acid metabolism (MAC), the gas exchange determinations were performed between 10:00 p.m. and 12:00 a.m., according to Nobel (2001), due to the higher $\mathrm{CO}_{2}$ capture at this time. The

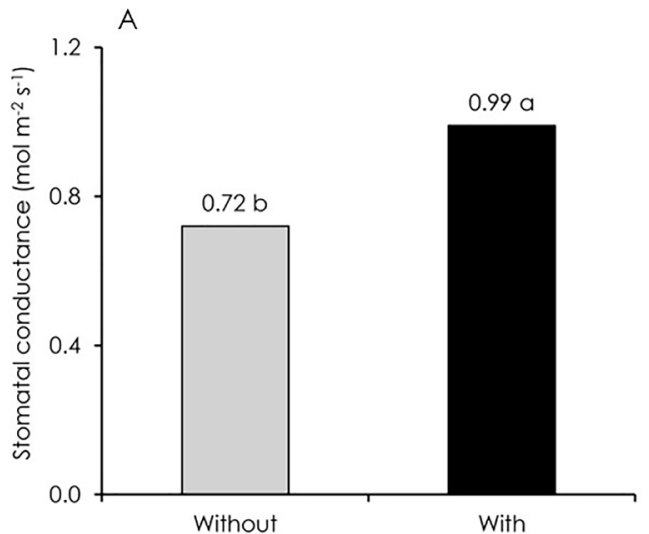

Figure 1. Stomatal conductance $\left(g_{s}\right)(A)$ and transpiration rate $(E)(B)$ in forage cactus plants (Nopalea Cochenillifera Salm Dick) as a function of soil mulch.

This addition in the transpiration rate is a consequence of the greater stomatal opening and root activity, obtained through the lower water deficit provided by the maintenance of soil moisture and temperature at adequate levels to the plants (Fernandes et al., 2015).

The Nopalea forage cactus, besides xerophilic, that is, naturally adapted to dry environments, is governed by the crassulacean acid metabolism (MAC), presenting as a marked physiological characteristic the opening of measurements were performed in two plants per plot, with readings performed in two mature cladodes per plant, characterized by holding from one to two young cladodes. A portable infrared gas analyzer (IRGA) (model LI-COR 6400-XT, Lincoln, USA) was used to perform the evaluations. The protocol for the IRGA evaluations was: RFA (photosynthetically active radiation) turned off; air relative humidity within $50-60 \%$; airflow of $200 \mathrm{mmol} \mathrm{s}^{-1}$, and atmospheric $\mathrm{CO}_{2}$ concentration of $400 \mathrm{\mu mol} \mathrm{mol}^{-1}$, with leaf chamber diameter of $6 \mathrm{~cm}^{2}$.

The results were subjected to analysis of variance by the $\mathrm{F}$ test, which is conclusive for one degree of freedom, such as in the data regarding the mulch factor. However, the types of cultivation (intercropping systems), when presenting a significant difference by F-test, were compared by Tukey's test at a $5 \%$ level of probability. The Statistical Analysis System ${ }^{\circledR}$ software was used to process the data.

\section{Results and Discussion}

The use of soil mulch provided a higher stomatal conductance to the forage cactus plants, increasing from 0.72 to $0.99 \mathrm{~mol} \mathrm{~m}^{-2} \mathrm{~s}^{-1}$ (Figure 1A), an increase of $27.28 \%$. This behavior was also observed for the transpiration rate, with an increment from 3.61 to $4.89 \mathrm{mmol} \mathrm{m}^{-2} \mathrm{~s}^{-1}$ as a function of the use of this conservationist technique (Figure 1B).

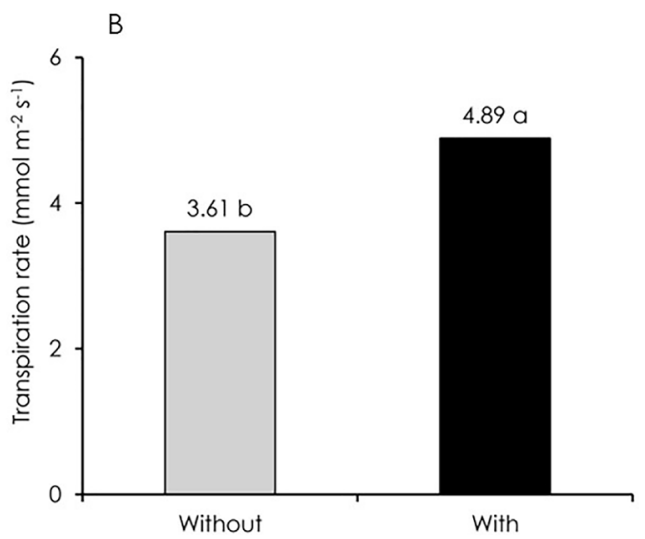

stomata during the night, when the vapor-pressure deficit is lower. This often occurs in the region of Soledade-PB, located at 521 meters above sea level, where there is dew formation during the night, a favorable condition for the development of cacti (Taiz et al., 2017; Cajazeira et al., 2018).

In the intercropped system with buffelgrass (FC $x$ $B$ ) and forage watermelon ( $F C \times F W)$, the forage cactus obtained the highest values for the photosynthesis rate (5.63 and $5.23 \mu \mathrm{mol} \mathrm{m} \mathrm{m}^{-2} \mathrm{~s}^{-1}$ ), overcoming by 36.6 and 31.7 
$\%$, respectively, the plants cultivated in monoculture (Figure 2A). In the intercropping between forage cactus and millet $(F C \times M)$ and between forage cactus and sorghum $(F C \times S)$, the data differ statistically, presenting a variation of $0.64 \mu \mathrm{mol} \mathrm{m} \mathrm{m}^{-2} \mathrm{~s}^{-1}$ (Figure 2A). Such as observed in Figure 1, soil mulch increased the photosynthesis rate of the plants from 3.1 to $6.0 \mu \mathrm{mol} \mathrm{m} \mathrm{m}^{-2} \mathrm{~s}^{-1}$, an increase above 48.3\% (Figure 2B).
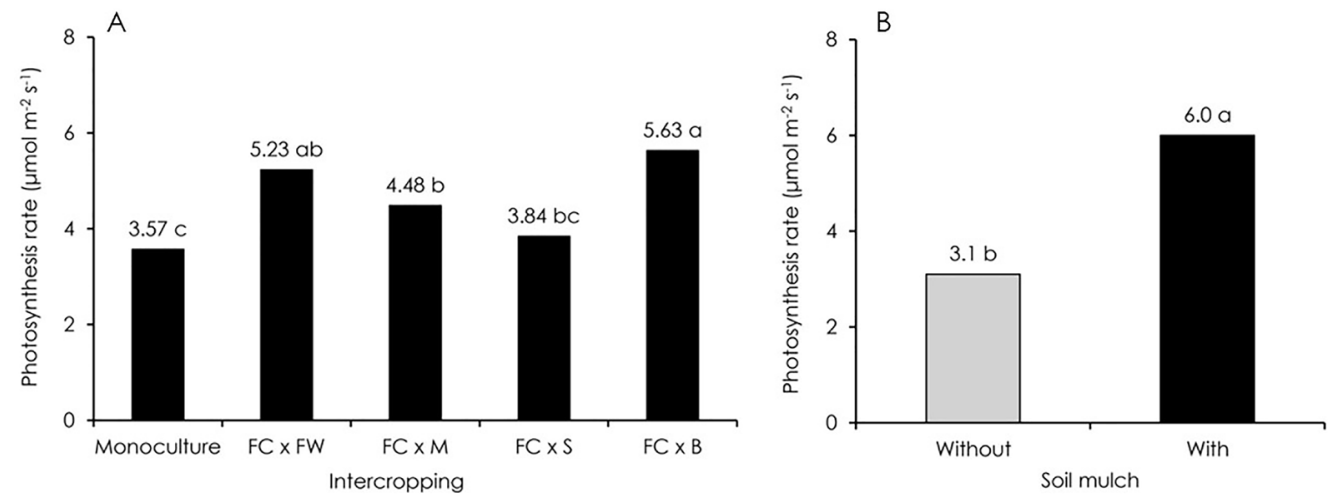

Figure 2. Photosynthesis rate (A) in forage cactus plants (Nopalea Cochenillifera Salm Dick) as a function of different intercropping systems (A) and soil mulch (B).

$\mathrm{FC}=$ Forage cactus; $\mathrm{FW}=$ Forage watermelon; $\mathrm{M}=$ Millet; $\mathrm{S}=$ Sorghum; $\mathrm{B}=$ Buffelgrass. Columns with the same letters do not differ from each regarding the type of intercropping by Tukey's test at $\mathrm{p} \leq 0.05(\mathrm{~A})$.

Sampaio (2005) highlights that in the intercropping of forage cactus with $\mathrm{C}_{3}$ and $\mathrm{C}_{4}$ crops, both can benefit since, during the night, these plants are in the process of respiration, that is, releasing $\mathrm{CO}_{2}$ to the atmosphere, creating an environment richer in $\mathrm{CO}_{2}$ in the space between the soil and the upper part of the plant. This higher $\mathrm{CO}_{2}$ concentration leads to a more intense photosynthesis process by the forage cactus (Nobel, 2001).

The height of the plants possibly contributed to these results since in the evaluation period the forage cactus plants presented height from 40 to $60 \mathrm{~cm}$, facilitating this higher $\mathrm{CO}_{2}$ concentration promoted by the forage watermelon and buffelgrass plants in comparison with the millet and sorghum crops, which were more than a meter high.

Nobel (2009) highlights that the plants governed by the MAC present a maximum photosynthesis rate of $7.6 \mu \mathrm{mol} \mathrm{m} \mathrm{m}^{-2} \mathrm{~s}^{-1}$, although the rate is normally $2.5 \mu \mathrm{mol}$ $\mathrm{m}^{-2} \mathrm{~s}^{-1}$. These low photosynthesis rates, in most cases, cause the plant to present a very slow growth; however, it is observed that the plants evaluated in this research, especially those cultivated in the soil under mulch cover, presented photosynthesis rates above this average rate. This may be an indicator of the highest growth rate of the forage cactus, which allows annual harvests for the crop in comparison to native cacti, which possess a slower annual growth rate.

The relative advantages of the use of soil mulch on the photosynthesis rates of the plants possibly occurred due to the reduction of the negative effects of solar radiation, such as the wind speed on the edaphic surface, essential in semiarid soils, in which the reference evaporation can reach $12 \mathrm{~mm} / \mathrm{day}^{-1}$ even in the rainy season, more precisely in the first semester. The highest stomatal conductance observed in the plants cultivated under this edaphic management (Figure 1A) stimulated the photosynthesis rate as a function of the greater stomatal opening and the greater availability of substrate for the activity of RUBISCO during the day (Souza et al., 2016).

The use of soil mulch is a recommended practice, particularly for these regions, since besides maintaining the soil more humid and less heated, it reduces soil water losses and also superficial erosion, contributing to the improvement of crop performance (Lima et al., 2015). Borges et al. (2014) evidenced in maize cultivation (Zea mays L.), in the semiarid region of Pernambuco, that soil mulch, besides increasing the growth and productive indices of the crop, acted efficiently with the conservationist management practice, contributing to a better use of rainwater and lower soil loss in the cultivation, compared to the uncovered system.

The internal carbon concentration (Figure 3) was influenced by the type of intercropping and soil mulch since, in all situations, the use of soil mulch with vegetal residues increased the internal $\mathrm{CO}_{2}$ in the forage cactus plants by at least $7.6 \%$.

In the soil covered with vegetal remains, the FC $\times B ; F C \times M$, and FC $\times S$ intercropping systems provided higher values for this variable, whereas in the uncovered soil the highest results were obtained with the $\mathrm{FC} \times \mathrm{B}, \mathrm{FC}$ $\times M$, and FC $\times$ FW intercropping systems (Figure 3). For Santos et al. (2016), the use of mulch provided good 


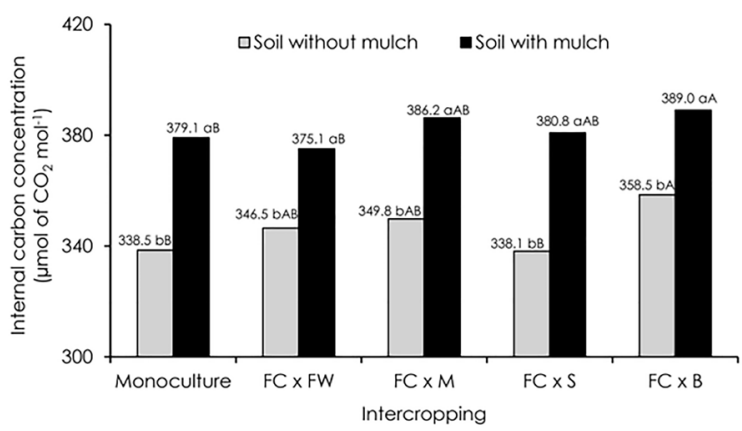

Figure 3. Internal carbon concentration $\left(C_{i}\right)$ in forage cactus plants (Nopalea Cochenillifera Salm Dick) as a function of different types of intercropping in the soil without and with mulch.

$\mathrm{FC}=$ Forage cactus; $\mathrm{FW}=$ Forage watermelon; $\mathrm{M}=$ Millet; $S=$ Sorghum; $B=$ Buffelgrass. Columns with the same lowercase letters in the same intercropping type do not differ regarding the mulch factor, and columns with the same uppercase letter do not differ as for the intercropping type by Tukey's test at $p \leq 0.05$.

water conditions in the soil, mitigating the manifestation of severe water stress, which, along with the possible adequate nutritional condition provided by the chemical and organic fertilization performed during the research, provides maintenance conditions for the photosynthetic metabolism.

The higher stomatal conductance $\left(g_{s}\right)$ of the plants cultivated in the mulched soil (Figure 1A) contributed directly to these results since the increment in the $C_{i}$ values is accompanied by increases in the $g_{s}$; therefore, the stomatal limitation would be the main factor for the restriction of the photosynthetic performance, considering that the greater is the stomatal opening, the greater will be the $\mathrm{CO}_{2}$ partial pressure in the intercellular spaces, favoring the diffusion of $\mathrm{CO}_{2}$ for the substomatal cavity, and thus increasing the substrate for the activity of Ribulose 1,5 biphosphate carboxylase/oxygenase (Rubisco) (Silva et al., 2015; Souza et al., 2016).

The instantaneous carboxylation efficiency (iCE) of the forage cactus, resembling the remaining physiological variables, was superior in the plants cultivated in the mulched soil (Figure 4A), increasing from 0.008 to $0.017 \mu \mathrm{mol} \mathrm{m} \mathrm{m} \mathrm{s}^{-1} / \mu \mathrm{mol}$ of $\mathrm{CO}_{2} \mathrm{~mol}^{-1}$, an increment above $52 \%$. These increments observed in the gas exchange of the plants cultivated in the mulched soil are possibly a consequence of moisture maintenance, and also of the reduction of temperature in the edaphic profile, a situation already verified by Zhao et al. (2014) in assays performed in the semiarid region of China. For Silva et al. (2016), increments in the iCE are directly related to increased (Figure 1A) and intracellular concentration of $\mathrm{CO}_{2}$ (Figure 3 ) as a function of the greater availability of ATP, NADPH, and the substrate for Rubisco.
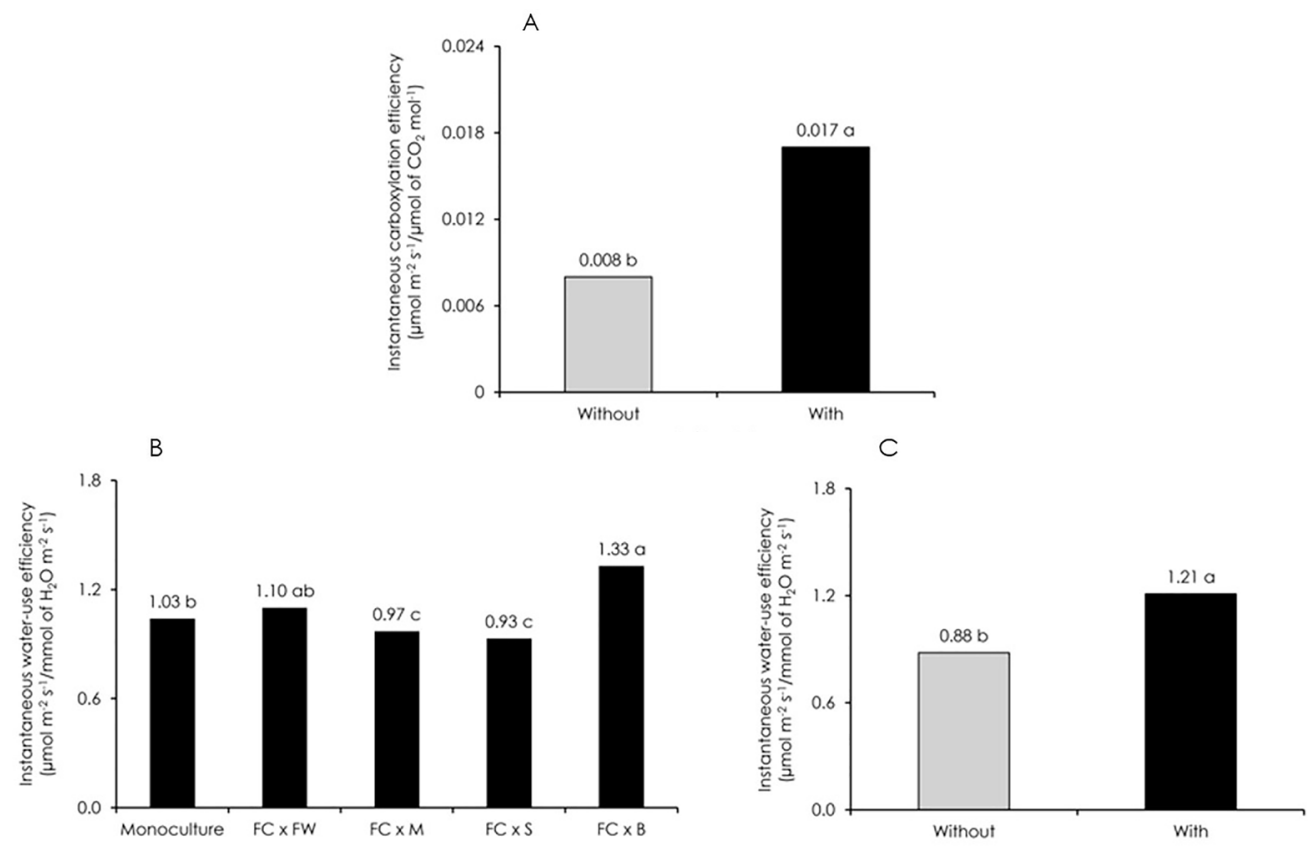

Figure 4. Instantaneous carboxylation efficiency (iCE) as a function of the use of mulch (A) and instantaneous water-use efficiency (WUE) in Nopalea forage cactus plants (Nopalea Cochenillifera Salm Dick) as a function of different intercropping types (B) in the soil without and with mulch (C). $\mathrm{FC}=$ Forage cactus; $\mathrm{FW}=$ Forage watermelon; $\mathrm{M}=$ Millet; $\mathrm{S}=$ Sorghum; $\mathrm{B}=$ Buffelgrass. Columns with the same letters do not differ from each other regarding the type of intercropping by Tukey's test at $\mathrm{p} \leq 0.05$ (A).

The instantaneous water-use efficiency (Figure $4 B)$ by the forage cactus was favored ( $p \leq 0.05)$ when of the intercropping with buffelgrass and forage watermelon $\left(1.33\right.$ and $1.10 \mu \mathrm{mol} \mathrm{m} \mathrm{m}^{-2} \mathrm{~s}^{-1} / \mathrm{mmol}$ of $\mathrm{H}_{2} \mathrm{O}$ $\mathrm{m}^{-2} \mathrm{~s}^{-1}$, respectively). This is caused by the increase in photosynthesis in response to the higher transpiration 
rates, determining an increment of this variable. Such as in the photosynthesis rate (Figure 2A), it is observed that the intercropping with larger crops, such as millet and sorghum, reduced the WUE for this cactus species. This is possibly the consequence of the shading caused by these crops, decreasing the consumption of malate during the day due to a deficiency in the photochemical system, causing a reduction in the primary fixation of $\mathrm{CO}_{2}$ at night by the forage cactus (Sampaio, 2005).

According to Cajazeira et al. (2018), the importance of the quantification of the water-use efficiency by the plant is fundamental to evaluate how much water is lost by the transpiration process in the gas exchanges and, consequently, the assimilation of atmospheric $\mathrm{CO}_{2}$ to integrate compounds. Regarding this aspect, Ferreira et al. (2012) highlight that the highest values of A are normally accompanied by high rates of $E$ and $g_{s^{\prime}}$ for several species, and it leads to a reduction in the WUE, especially in tropical regions, a situation that occurred in the present study regardless of the type of intercropping or edaphic management. This variable was also increased by $0.33 \mu \mathrm{mol} \mathrm{m} \mathrm{m}^{-2} \mathrm{~s}^{-1} / \mathrm{mmol} \mathrm{H}_{2} \mathrm{O} \mathrm{m} \mathrm{m}^{-2} \mathrm{~s}^{-1}$ with the use of soil mulch, corresponding to a $27.3 \%$ gain in the water-use efficiency by plants (Figure 4C).

Regarding the intrinsic water-use efficiency (iWUE), obtained by the ratio between photosynthetic rate and stomatal conductance, it is noted that the intercropping of buffelgrass and forage watermelon resulted in considerable increases $(26.7$ and $21.7 \%$, respectively) in the iWUE of the Nopalea forage cactus plants, in comparison with the monoculture system (Figure 5A). The increase in the iWUE values indicate that there was an increase of net photosynthesis even with a lower stomatal conductance, that is, the $g_{s}$ reduction was relatively greater than the reduction in A, supporting the occurrence of stomatal limitation (Bertolli et al., 2015). Silva et al. (2013) observed that the intercropping between oleaginous plants and forage cactus, in dryland cultivation, presented positive results regarding land-use efficiency and gross income, and may constitute an efficient alternative in family agriculture since these are important parameters in the efficiency evaluation of the system.
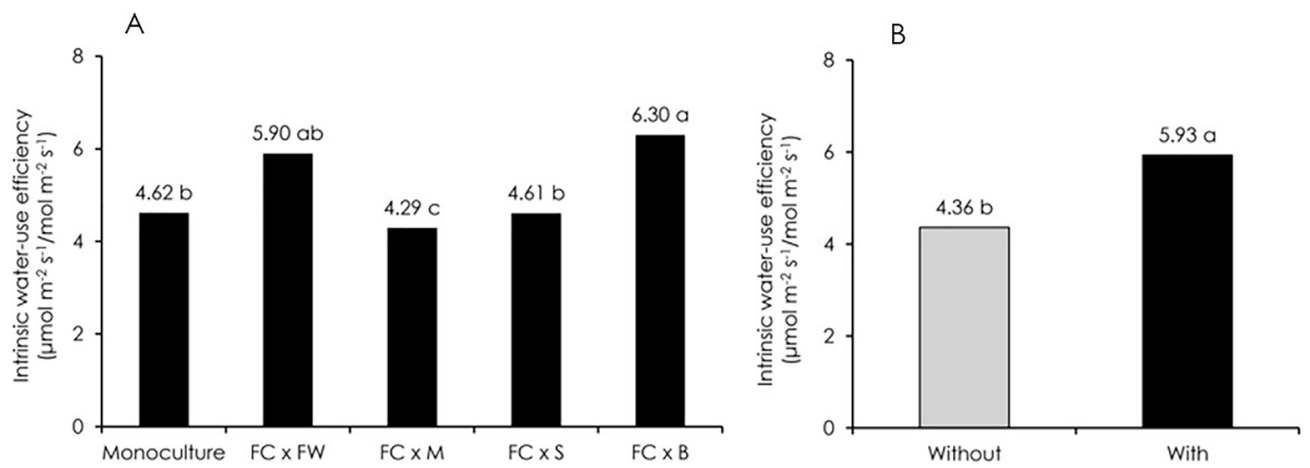

Figure 5. Intrinsic water-use efficiency in cactus forage plants (Nopalea Cochenillifera Salm Dick) as a function of different types of intercropping (A) in the soil without and with mulch (B).

$\mathrm{FC}=$ Forage cactus; $\mathrm{FW}=$ Forage watermelon; $\mathrm{M}=$ Millet; $\mathrm{S}=$ Sorghum; $\mathrm{B}=$ Buffelgrass. Columns with the same letters do not differ from each other regarding the type of intercropping by Tukey's test at $\mathrm{p} \leq 0.05(\mathrm{~A})$.

The addition of soil mulch stimulated the iWUE by $26.5 \%$ (Figure $5 \mathrm{~B}$ ). This situation is caused by the simultaneous increase in photosynthesis governed by the greater stomatal conductance (Figures $1 \mathrm{~A}$ and $2 \mathrm{~B}$ ), demonstrating that, in semiarid zones, conservationist practices such as edaphic covering with vegetal remains can provide greater stomatal dynamics to the plants, thus increasing the rates of water-use efficiency.

\section{Conclusions}

The plants presented greater photosynthetic capacity when cultivated in the mulched soil;

The intercropping with smaller plants, such as buffelgrass and forage water melon, stimulated photosynthesis and water-use efficiency by the Nopalea forage cactus.

\section{References}

Alvares, C.A., Stape, J.L., Sentelhas, P.C., Gonçalves, J.L.M., Sparovek, G. 2013. Köppen's climate classification map for Brazil. Meteorologische Zeitschrift 22: 71 1-728.

Andrade, B.M.S., Souza, S.F., Santos, C.M.C., Medeiros, S.S., Mota, P.S.S., Curado, F.F. 2015. Uso da gliricídia (Gliricidia sepium) para alimentação animal em Sistemas Agropecuários Sustentáveis. Scientia Plena 1 1: 1-7.

Bertolli, S.C., Souza, J., Souza, G.M. 2015. Caracterização fotossintética da espécie isohídrica Pata-de-Elefante em condições de deficiência hídrica. Revista Caatinga 28: 196-205. 
Borges, T.K.S., Montenegro, A.A.A., Santos, T.E.M., Silva, D.D., Silva Junior, V.P. 2014. Influência de práticas conservacionistas na umidade do solo e no cultivo do milho (Zea mays L.) em Semiárido nordestino. Revista Brasileira de Ciência do Solo 38: 1862-1873.

Cajazeira, J.P., Correa, M.C.M., Almeida, E.I.B., Queiroz, R.F., Mesquita, R.O. 2018. Growth and gas exchange in white pitaya under different concentrations of potassium and calcium. Revista Ciência Agronômica 49: 112-121.

Costa, N.D., Faria, C.M.B., Pereira, J.R. 2008. Recomendação de adubação para a melancia. In: Cavalcanti, F.J.A. (ed.) Recomendações de adubação para o estado de Pernambuco: $2^{a}$ Aproximação. Instituto Agronômico de Pernambuco, Recife, Brazil. 171 p.

Diniz, W.J.S., Silva, T.G.F., Ferreira, J.M.S., Santos, D.C. Moura, M.S.B., Araújo, G.G.L., Zolnier, S. 2017. Forage cactus-sorghum intercropping at different irrigation water depths in the Brazilian Semiarid Region. Pesquisa Agropecuária Brasileira 52:724-733.

EMBRAPA - National Soil Research Center. 2013. Brazilian system of soil classification. Embrapa, Brasília, Brazil.

Ferreira, M.J., Carvalho, G.J.F., Ferraz, J.B.S. 2012. Crescimento e eficiência do uso da água de plantas jovens de Castanheira-da-Amazônia em área degradada e submetidas à adubação. Ciência Florestal 22: $393-401$

Fernandes, F.B.P., Lacerda, C.F., Andrade, E.M., Neves, A.L.R., Sousa, C.H.C. 2015. Efeito de manejos do solo no déficit hídrico, trocas gasosas e rendimento do feijãode-corda no Semiárido. Revista Ciência Agronômica 46: 506-515.

Jardim, A.M.R.F., Silva, J.R.I., Leite, M.L.M.V., Teixeira, V.I., Morato, R.P., Araujo Junior, G.N., Silva, T.G.F. 2018. Symbiotic interaction in forage crop cultivations: A review. Amazonian Journal of Plant Research 2: 149-160.

Lima, C.A., Montenegro, A.A.A., Santos, T.E.M., Andrade, E.M., Monteiro, A.L.N. 2015. Práticas agrícolas no cultivo da mandioca e suas relações com o escoamento superficial, perdas de solo e água. Revista Ciência Agronômica 46: 697-706.

Lima, L.R., Silva, T.G.F., Pereira, P.C., Morais, J.E.F., Assis, M.C.S. 2018. Productive-economic benefit of forage cactus-sorghum intercropping systems irrigated with saline water. Revista Caatinga 31: 191-201.

Nobel, P.S. 2001. Biologia ambiental. In: Barbera, G, Inglese, P., Pimienta Barros, E. (ed.) Agroecologia, cultivo e usos da palma forrageira. FAO, João Pessoa, Brazil. p. 36-48.

Nobel, P.S. 2009. Physicochemical and Environmental Plant Physiology. Academic Press, California, USA. 604 p.

Ramos, J.P.F., Souza, J.T.A., Santos, E.M., Pimenta Filho, E.C., Ribeiro, O.L. 2017. Crescimento e Produtividade de Nopalea Cochenillifera em função de diferentes densidades de plantio em cultivo com e sem capina. Revista Electrónica de Veterinária 18: 1-12.
Sampaio, E.V.S.B. 2005. Fisiologia da palma. In: Menezes, R.S.C., Simões, D.A., Sampaio, E.V.S.B. (ed.) A palma no Nordeste do Brasil: Conhecimento atual e novas perspectivas. Editora Universitária UFRPE, Recife, Brazil. p. 43-56.

Santos, D.C., Lira, M.A., Dubeux Júnior, J.C.B., Santos, M.V.F., Mello, A.C.L. 2008a. Recomendação de adubação para a palma forrageira. In: Cavalc anti, F.J.A. (ed.) Recomendações de adubação para o estado de Pernambuco: $2^{a}$ Aproximação. Instituto Agronômico de Pernambuco, Recife, Brazil. 178 p.

Santos, E.S., Montenegro, A.A.A., Pedrosa, E.M.R., Silva, Ê.F.F. 2016. Crescimento e produção de repolho sob diferentes adubações na presença e ausência de cobertura morta em agricultura familiar. Irriga 21: 74-89.

Santos, M.R., Silva, A.J.P., Fonseca, V.A., Campos, A.R.F., Lisboa, M.A. 2017. Irrigação na palma forrageira. Informe Agropecuário 38: 76-90.

Silva, J.G.M., Melo, A.A.S., Rego, M.M.T., Lima, G.F.C., Aguiar, E.M. 2011. Cactáceas nativas associadas a fenos de flor de seda e sabiá na alimentação de cabras leiteiras. Revista Caatinga 24: 158-164.

Silva, G.S., Oliveira, R.A., Queiroz, N.L., Silva, M.N.B., Sousa, M.F., Silva, S.A. 2013. Desempenho agronômico de algodão orgânico e oleaginosas consorciados com palma forrageira. Revista Brasileira Engenharia Agrícola Ambiental 17: 975-981.

Silva, F.G., Dutra, W.F., Dutra, A.F., Oliveira, I.M., Filgueiras, L.M.B., Melo, A.S. 2015. Trocas gasosas e fluorescência da clorofila em plantas de berinjela sob lâminas de irrigação. Revista Brasileira de Engenharia Agrícola e Ambiental 19: 946-952.

Silva, A., Brito, M.E.B., Frade, L.J.G., Nobre, R.G., Costa, F.B., Melo, A.S., Silva, L.A. 2016. Crescimento e trocas gasosas de genótipos de feijão-caupi sob estratégias de cultivo. Revista Ambiente \& Água 11: 745-758.

Souza, T.M.A., Souza, T.A., Souto, L.S., Sá, F.V.S., Paiva, E.P., Brito, M.E. B. Mesquita, E.F. 2016. Crescimento e trocas gasosas do feijão caupi cv. BRS pujante sob níveis de água disponível no solo e cobertura morta. Irriga 21: 796805.

Sun, Q., Wang, Y., Chen, G., Yang, H., Du, T. 2018. Water use efficiency was improved at leaf and yield levels of tomato plants by continuous irrigation using semipermeable membrane. Agricultural Water Management 203: 430437.

Tabosa, J.N., Tavares Filho, J.J., Santos, D.C., Simplício, J.B., Tavares, A.A, Nascimento, M.M.A., Lira, Brito, A.R.M.B, Silva, A.B., Coltinho, G.V. 2008a. Recomendação de adubação para o milheto forrageiro. In: Cavalcanti, F.J.A. (ed.) Recomendações de adubação para o estado de Pernambuco: $2^{a}$ Aproximação. Instituto Agronômico de Pernambuco, Recife, Brazil. 173 p.

Tabosa, J.N., Tavares Filho, J.J., Santos, D.C., Simplício, J.B., Tavares, A.A, Nascimento, M.M.A., Brito, A.R.M.B., Silva, A.B., Coltinho, G.V. 2008b. Recomendação de 
adubação para o sorgo forrageiro. In: Cavalc anti, F.J.A. (ed.) Recomendações de adubação para o estado de Pernambuco: $2^{a}$ Aproximação. Instituto Agronômico de Pernambuco, Recife, Brazil. $191 \mathrm{p}$.

Taiz, L., Zeiger, E., Moller, I.M., Murphy, A. 2017. Fisiologia e Desenvolvimento Vegetal. Artmed, Porto Alegre, Brazil. $819 \mathrm{p}$.

Tomas, M., Medrano, H., Escalona, J.M., Martorell, S., Pou, A., Ribas-Carbo, M., Flexas, J. 2014. Variability of water use efficiency in grapevines. Environmental and Experimental Botany 103: 148-157.

Zhao, Y., Pang, H., Wang, J., Huo, L., Li, Y. 2014. Effects of straw mulch and buried straw on soil moisture and salinity in relation to sunflower growth and yield. Field Crops Reserch 2: 14-27.

Conflict of Interest Statement: The authors declare that the research was conducted in the absence of any commercial or financial relationships that could be construed as a potential conflict of interest.

All the contents of this journal, except where otherwise noted, is licensed under a Creative Commons Attribution License attribuition-type BY. 